Acta Universitatis Nicolai Copernici • Pedagogika XXXVII/1/2019

Nauki Humanistyczno-Społeczne • Zeszyt 447

DOI: http://dx.doi.org/10.12775/AUNC_PED.2019.002

\author{
Jerzy Bagrowicz \\ Nicolaus Copernicus University in Toruń \\ Professor Emeritus \\ ORCID: 0000-0003-3543-2973
}

\title{
Biblical EdUCATION: An introduction
}

\begin{abstract}
:
The Old and the New Testaments are not only the word of God and a source of wisdom that leads to salvation, but also a mine of knowledge and educational wisdom. One can speak of biblical pedagogy, which in a sense is a synthesis of God's wisdom revealed to the people of Israel and the educational experience which they gained over the centuries of their existence. Both the Old and the New Testaments, in their entirety, are a source of this pedagogy adopted by God with respect to the Chosen People both as a whole and as individuals. For the educational practice of Christianity, the basic code of ethical norms contained in the Ten Commandments, i.e. the Decalogue, is of particular importance, applying to all believers. These are the rules of conduct that provide the basis in the formation and education of a new person. Consequently, one cannot understand the principles of education based on the teachings of Jesus Christ without exploring the educational tradition of Israel and comprehending the pedagogy contained in the Old Testament. Jesus Christ did not reject this tradition; instead, he employed it and built on it further, revealing its much broader and deeper perspective. The biblical pedagogy also continues to be valid in the conditions of the modern world.
\end{abstract}

Key w ord s: Bible, pedagogy, education 


\section{STRESZCZENIE:}

Pismo Święte Starego i Nowego Testamentu jest nie tylko natchnionym słowem Bożym i źródłem mądrości służącej zbawieniu, ale jest także kopalnią wiedzy i mądrości wychowawczej. Można mówić o pedagogii biblijnej stanowiącej niejako syntezę objawionej ludziom przez Boga Jego zbawczej mądrości oraz doświadczenia wychowawczego, które lud Izraela zdobywał poprzez wieki swej historii. Cały Stary i Nowy Testament jest źródłem owej pedagogii, którą Bóg stosował wobec całego Narodu Wybranego, jak i wobec poszczególnych ludzi. Dla praktyki wychowawczej chrześcijaństwa istotny jest szczególnie podstawowy kodeks norm etycznych obowiązujących jego wyznawców, zawartych w Dziesięciu Przykazaniach czyli w Dekalogu. Są to reguły postępowania, które stały się podstawą wychowania i kształtowania nowego człowieka. Nie zrozumiemy zasad wychowania opartego na nauce Jezusa Chrystusa, jeśli nie wejdziemy w tradycję wychowawczą Izraela i nie odczytamy pedagogii zawartej w Starym Testamencie. Jezus Chrystus nie odrzucił tej tradycji, na niej budował, ukazując o wiele szersze i głębsze jej perspektywy. Pedagogia biblijna jest ciągle aktualna, także wobec uwarunkowań współczesnego świata.

Słowa klucze: Biblia, pedagogika, edukacja

\section{Introductory notes}

7 here are two types of sources which provide us with information $\perp$ about education and upbringing in ancient times: material objects of culture and written documents. The latter are of particular importance because they either speak directly about education in antiquity or allow us to draw interesting conclusions.

The first records referring to human education and upbringing can be traced back to the oldest Sumerian and Babylonian texts, followed by the somewhat younger ones from Ancient Egypt. Among those most interesting for the purposes of this article are texts classified as wisdom literature and school exercises. Based on these, it is possible to gain an understanding of the oldest records of teaching and upbringing. 
In ancient times, young people obtained their first education at home from their parents. Evidence of home teaching has been found both in Mesopotamia and Egypt. It followed the principle expressed by Ptahhotep, who said that: 'No one was born wise'. Consequently, a parent would instruct a child: 'Take advice from an educated person as well as from a wise one'1.

Chronologically, school was the second stage of forming young people's intellect. In Egypt, school was called the House of Life and taught not only the art of writing but also of correspondence, how to draw official documents and contracts. In Mesopotamia, the teacher's title was mumia ('the school father'), while students were sons of edubba ('house of clay tablets', 'scribal school').

A wealth of further information about teaching and upbringing can be found in the Bible. Although biblical texts are much younger, they have the advantage of being more extensive. They also constitute a significant part of a larger whole - the Old and New Testaments ${ }^{2}$. The Bible would not be a universal book if it did not present issues related to education in a manner whereby the latter was perceived and provided at the time when the Holy Scriptures were written, hence all the similarities both generally and in terms of education specifically between the Bible and ancient texts.

The originality of the biblical concept of education expresses itself through its coverage and religious motivation behind education. While in Egypt and the Middle East education was the privilege of the elite, in Israel it was addressed to all social classes, including the lowest ones,

1 J. Bagrowicz, S. Jankowski, 'Pan, Bóg twój, wychowuje ciebie' (Pwt 8, 5), Toruń 2005, pp. 11, 15-16 ['The Lord your God disciplines you' (Deuteronomy, 8:5); Unless indicated otherwise all Bible quotations in English come from the New Revised Standard Version Bible (NRSV), 1989]; cf. M. Civil, Education (Mesopotamia). In: D.N. Friedman (Editor-in-Chief), The Anchor Bible Dictionary, New York 1992, vol. 2 D-G, pp. 301-305; J. T. Townsend, Education (Greco-Roman), ibid., pp. 312-317; H.-I. Marrou, Historia wychowania $w$ starożytności (Histoire de l'éducation dans l'Antiquité), Warsaw 1969; cf. F. Gioia, Metodie ideali educativi dell' Antico Israele e del Vicino Oriente, Citta del Vaticano 2008, pp. 97-105.

2 Cf. J. L. Crenshaw, Education in ancient Israel: Across the deadening silence, New York 1998, pp. 15-27. 
although in their case the burden of young people's spiritual formation and vocational training rested entirely with the parents. Israel, much more so than its contemporaries, was aware of the need for universal education, which it perceived as guaranteeing the significance, survival and fulfilment of its historical mission. The second even more vivid and important difference between the upbringing of pagans compared to Israelites is that education through the Bible is and has always been clearly religiously motivated. While people in antiquity were typically extremely religious (cf. Acts 17, 22 ff.), they did not associate their religious beliefs with life principles or ethics; there was no common ground whereby faith and morality would somehow have an effect on each other. However, Israel was different in this respect as religiousness and morality were closely linked, with one preconditioning the other. The approach to one dictated the authenticity of the other. Their integration was possible through a manner of upbringing recognised by the Bible: firstly, as forming a person rather than a mere training technique that is to evoke a specific type of behaviour; and secondly, as focused on linking the professed truths of faith received in the Divine Revelation with the commandments given to the people (obligations arising from the covenant). Israelites find both the former and the latter in the Torah, which to them is not only 'the Law' but also God's Wisdom embodied by 'the book of the commandments of God, the Law that endures forever' (Baruch 4:1) ${ }^{3}$.

\section{The essence and purpose of education according to the Bible}

While the conviction regarding the need for upbringing/education seems to be a common belief, its doctrinal assumptions, models, goals and their implementation, methods, and educational measures remain subjects of a heated debate. Many approaches and points of view have been developed in this area, both historically and content-wise. Commonly perceived as a book that was created to teach and help people in

\footnotetext{
${ }^{3}$ J. Bagrowicz, S. Jankowski, op. cit., pp. 6-7.
} 
carrying out their life tasks, the Bible is one of many important voices in terms of the sources and practice of education; according to believers it carries words inspired by God and is therefore a source of wisdom on their path to salvation. Among many issues discussed in the Scriptures, one can also find statements concerning people, human nature and upbringing. In this respect it is replete with knowledge and wisdom regarding education.

The subject of education in the Old Testament is most widely discussed in the Wisdom Books, i.e. the Books of Proverbs, Job, Ecclesiastes (Qohelet), Sirach (Ecclesiasticus) and Wisdom, as well as a number of psalms and passages in other books. One should not forget that the entire Old Testament presents a certain pedagogy adopted by God with respect to the Chosen People both as a whole and as individuals. It may be first found in the Pentateuch, in the history of the Patriarchs, as well as in the Wisdom Books and in the writings of the prophets of Israel. In the New Testament this pedagogy is particularly visible in the teachings of Jesus and thus in the Gospels, as well as in the Pauline epistles, the Apocalypse of Saint John and in other texts throughout the volume. However, none of these passages contain a systematic treaty on education, a theory of education or indeed anything that could be recognised as a holistic educational system. The Bible refrains from adopting an academic approach to issues of key importance to people in terms of religion and ethics, alternatively offering its 'worldly wisdom'. With education included among those key issues, the Scriptures discuss rules to be followed by educators in their educational mission, measures to be applied, and goals that must be achieved through education, while providing examples of negligence that should be taken as a warning. Finally, the Bible uses pedagogy as a metaphor for a better understanding of actions leading to human salvation, taken first by God the Father in the Old Testament and then by God the Son in the New Testament. This article focuses on the educational tradition passed on by the books of the Old Testament.

The purpose of education according to the Bible is to learn, love and practice the Law, i.e. the Wisdom derived from God, while reverential fear of God and obedience dictated by filial affection towards God will determine its achievement. This is the primary purpose that falls with- 
in the categories of the pedagogy of salvation. However, many biblical texts contain references to a more natural purpose of raising people preparing them for their roles as individuals and as parts of the wider society. This means that the aims of education are discussed both in terms of religious faith and in the categories of natural education, both of which were closely related with each other in Israel's tradition of education. With this in mind, the Bible appears to be a noteworthy study of authentic educational wisdom.

The goal of 'upbringing and education was to interiorise the basic profession of faith and its obligations, which could be achieved both by learning them by heart and by the internally motivated observance of the commandments and prohibitions in everyday life ${ }^{4}$. This goal was achieved via different educational methods and measures. One method, still commonly used in teaching and education in Israel today, was to memorise the oral tradition passing down from generation to generation by family and teachers, along with the commentary that updated it. People relied on phylacteries, mezuzahs, religious rituals and practices to help them with remembering, recalling and reflecting on the truths they studied.

More important than the material objects, directing Israelites' thoughts towards their religious and national identity, were words that explained the meaning and wisdom of the commandments and principles while simultaneously providing instructions on how to live by those rules. Words designed to serve the purpose of human formation come in different literary forms. From the perspective of literary criticism one can find a plethora of literary genres and subgenres developed by the educational tradition of the people of Israel. In this respect, Israel was neither entirely original nor independent of its neighbours; similar forms were employed in Egypt, Mesopotamia, Phoenicia and Greece; they may be divided into general sources and those applied directly in the process of education. The former would commonly include proverbs, fables, riddles, anecdotes, allegories, novellas, myths, leg-

4 W. Chrostowski, Wychowanie i ksztatcenie młodego pokolenia $w$ przedwygnaniowym Izraelu. In: idem, Asyryjska diaspora Izraelitów i inne studia, Warsaw 2003, p. 154. 
ends, various types of stories, biographical inscriptions, lists of names, confessions of faith, and prayers. Among the less known genres, one may find parables, Haggadah, Midrash, apocalypse, Halakha, genealogies, etiological myths, treatises on the order of the world and nature, and reflections on the meaning of life. As for those sources applied directly in the process of education, we can refer to exhortations, instructions, advice, encouragement, caution, admonition, conjuration, and threats. The wisdom literature in the Bible uses all these forms to spread faith, shape worldviews and form attitudes and beliefs of young generations. Instructions, encouragement, admonition and reproach are the most common verbal forms of forming students.

The basic motivation of people of the Bible behind raising/educating their children/students is love, which is understood as a desire for the good and wellbeing of one's pupil, caring about their interests and being responsible for them. Love is a stronger driving force with regards to education than of any other field of human activity because it addresses a person as a whole and is by its nature oriented towards good, while education communicates this goodness. However, a student's wellbeing - perceived as the goal of education - is not the only object of educational care and responsible love. Educational measures discussed by the Old Testament also originate from educational love. One of the authors of the Book of Proverbs says 'Those who spare the rod hate their children, but those who love them are diligent to discipline them' (Proverbs 13:24), while Sirach claims that 'Whoever spoils his son will bind up his wounds, and will suffer heartache at every cry' (Sirach 30:7). The Scriptures assume that the educator's love lies/must lie at the foundation of educating (forming) every young person ${ }^{5}$.

The Old Testament presents education as an important element of anthropology; however, there is much more to it as it also perceives and reveals education as an element of soteriology, the history of salvation. In this portrayal, God's human-oriented actions function as pedagogy. The passage in Deuteronomy reads: 'The Lord your God disciplines you' (Deuteronomy 8:5). The Bible emphasises that God reproves

\footnotetext{
5 J. Bagrowicz, S. Jankowski, op. cit., pp. 19-21.
} 
(disciplines, educates) humans as a father does so to his son (see Proverbs 3:11-12).

\section{Foundations of biblical education}

At the very foundation of the educational impact of the Old Testament lie the teachings on human dignity. Their basis is immediately presented on the very first pages of the Bible in its descriptions of the origins of humankind. The Book of Genesis offers two descriptions of the creation of humans. The first uses a significant expression to elevate humans and their dignity: 'Let us make humankind in our image, according to our likeness (...). So God created humankind in his image, in the image of God he created them' (Genesis 1:26-27). The second description of the creation of humans indicates that people were created as God's collaborators to further improve the world: 'The Lord God took the man and put him in the garden of Eden to till it and keep it' (Genesis 2:15).

Unlike animals, man was given the breath of God. It is not only a source of physical life but it also highlights the elevation of humans in relation to other creatures. People give names to animals and thus confirm their authority over them. Humans are depicted as capable of a dialogue with God; they are free beings who can take decisions about themselves.

The Book of Genesis makes further references to human dignity and its description: 'Whoever sheds the blood of a human, by a human shall that person's blood be shed; for in his own image God made humankind' (Genesis 9:6). Consequently, murder is stigmatised and punishable by death because the image of God is reflected in every person. Human life is inviolable and this right continues to prevail despite the various changes throughout human history: it is an unchangeable good that derives from the fact that humans were made in the image of God. This belief is addressed many times throughout the Bible, most explicitly in the Book of Wisdom: 'For God created us for incorruption, and made us in the image of his own eternity' (Wisdom 2:23). 
The idea of humankind created in the image of God vests a particular, sacred dignity in humans. Human dignity is therefore dictated neither by religion nor by the human condition but by sheer humanity; people cannot be reduced to the role of an object because God formed them to carry the 'mark' of God himself. This spiritual connection between humans and God is the key to the mystery of humankind: humans were presented with values that extend beyond empirical research. People were created in the image and with the likeness of God, which - in light of the entire Revelation - means that humans were the only creatures upon which God decided to bestow part of his own life and power. The image of God implanted in humans at the time of creation marks the beginning of the solidarity between God and humankind, with its pivotal moment being the Incarnation of God the Son ${ }^{6}$.

Another important element or foundation of biblical teachings on human education is the pedagogy contained in the Covenant Code. Israel was aware of its complete dependence on God, a conviction that was further reinforced by the act of covenant. By establishing a covenant with Israel and making promises to its people, God also set certain conditions that Israel undertook to keep. Israel committed itself to respecting all of God's statutes and commandments, which soon were to spin around its entire existence as a dense web of regulations ${ }^{7}$. God's instructions were communicated to the people through Moses, and the people committed themselves to obeying them: 'The people all answered as one: "Everything that the Lord has spoken we will do"' (Exodus 19:8). Having pleaded their obedience, they made their historical future dependent on fulfiling the promises made to God: 'If you will only obey the Lord your God, by diligently observing all his commandments that I am commanding you today, the Lord your God will set you high above all the nations of the earth' (Deuteronomy 28:1); 'But if you will not obey me, and do not observe all these commandments, if you spurn my statutes (...), I in turn will do this to you (...). I will set my face against you, and you shall be struck down by your enemies; your

\footnotetext{
6 Cf. M. Filipiak, Biblia o człowieku, Lublin 1979, pp. 79-87.

7 Słownik Teologii Biblijnej, Poznań 1973, p. 827.
} 
foes shall rule over you, and you shall flee though no one pursues you' (Leviticus 26:14-17).

However, as the history of Israel shows, alongside numerous proofs of loyalty to the covenant, acts of disobedience were not uncommon. Despite the clear presence of God Yahweh with his people and his fatherly protection ever since their liberation, Israelites would soon forget his acts of kindness: 'and in the wilderness, where you saw how the Lord your God carried you, just as one carries a child, all the way that you travelled until you reached this place. But in spite of this, you have no trust in the Lord your God, who goes before you on the way' (Deutronomy 1:31-33).

Prophets accuse Israel of infidelity towards God, foretelling its defeats and misfortunes as a consequence. For example, Ezekiel presents the history of salvation as a chain of nearly futile attempts for people to be led by God. Chapter XX of the Book of Ezekiel is a record of the history of Israel's infidelity: 'They did not observe my statutes but rejected my ordinances, by whose observance everyone shall live' (Ezekiel 20:13). They are further called 'rebels' who are 'impudent and stubborn' (cf. Ezekiel 2:3 ff.).

Nevertheless, even when they turn out to be obstinate and do not obey the covenant, God does not give up on educating his people: 'And you shall know that I am the Lord, when I deal with you for my name's sake, not according to your evil ways, or corrupt deeds, O house of Israel' (Ezekiel 20:44). In fact, when it comes to the people, one could say that the more educational problems they cause, the more determined God is in his subsequent initiatives to salvage them, lead them in life, and deliver them from sin; he never ceases to be with them and never turns away from them. This is a certain type of 'covenant pedagogy', some elements of which will be discussed here, albeit briefly.

\section{Crucial elements of covenant pedagogy}

The history of the Old Covenant is not just a story that describes the fate of a newly forming people, neither is it merely a record of Israel's rights 
and obligations. In fact, it is a unique story which unfolds as a chronicle of a deeply personal relationship between Yahweh and a community of people: Israel. One should keep this in mind when reading the Bible. The covenant is the basic act through which this highly personal relationship is expressed. Made with Abraham and Moses, the covenant is constantly renewed. Yahweh uses the voices of his prophets to reinforce the covenant and its law, the Torah.

This specific and original pedagogy manifests itself first through the covenant itself and then through God's presence with his people. Before God gave Moses the Tables of the Law, typically referred to as the Decalogue, he was known precisely as the one who is - who is with his people. This is an important statement not only from the theological but also from the pedagogical perspective; it reveals God as the one who accompanies the patriarchs in their nomadic life, wanders with them, guides them, looks after them and communicates his will through his words ${ }^{8}$.

This manner of God's presence is also indicated in God's revelation of his name through Moses: 'But Moses said to God, "If I come to the Israelites and say to them, 'The God of your ancestors has sent me to you,' and they ask me, 'What is his name?' what shall I say to them?" God said to Moses, "I AM WHO I AM." He said further, "Thus you shall say to the Israelites, "I AM has sent me to you"' (Exodus 3:13-14).

This statement should not be understood in philosophical terms but in a very specific Israelite comprehension of reality. It means: 'I am God to you. God who gives himself to you. From now on I would like you to know my power and my actions to a fuller extent than ever before, to experience them both in your salvation from Egypt and in the covenant that I offer you'9. Thus, this is the presence of God who is for his people, functioning as their educator.

God's relationship with Israel, at both an individual and collective level, is expressed in the Old Testament over a hundred times through the formula 'to be with'. One should remember that this formula applies

8 Cf. H. Muszyński, Bóg Abrahama, Izaaka i Jakuba, Bóg Ojców naszych, “Ateneum Kapłańskie”, no. 114 (1990), pp. 6-9.

9 Ibidem, p. 10. 
to people who are a nation of shepherds and are therefore constantly on the move, looking for new pastures for their herds. Understandably, such a formula must have had a very specific meaning within this nomadic culture ${ }^{10}$.

This is also an opportunity to see the foundation of God's pedagogy. He wants people to be able to constantly develop in their progress towards the future, towards their complete communion with God. He offers a lesson on the eschatological vision of life as a path that leads towards fulfilment in God. In this context, people acquire a specific spirituality by opening to Infinity and ethics embodied by transience of life and responsibility before $\operatorname{God}^{11}$. As well as providing life with meaning, this also results in a pedagogy of people capable of continuous development. Yahweh is the one who stimulates this process and accompanies it.

God is also with his people during their wanderings after they were liberated from Egypt and on their way to Canaan. This stage of the Israelites' history is colourfully described in the Pentateuch and Psalms (e.g. Psalms 78, 105, 106, 135, 136), and then further reflected upon in the Wisdom Books (see Sirach 44-45, Wisdom 11-19). However, this stage wherein the Israelites wander through the desert cannot be perceived only in historical or even historical-soteriological categories. Biblical scholars have highlighted the educational significance of this stage in Israel's life, emphasising that the pedagogical presence of God with his people is even more visible during this period of purification and consolidation of their faith.

An entire complex of events, from the liberation of Jacob's generations after 430 years in Egyptian captivity followed by 40 years of their wanderings in the desert, contributed to God's work of forming (educating) a nation. The goal was not only to reach a specific place but also to create a new human that would be free from the mentality of subservience and slavery. As outlined in the Pentateuch, it was neither a simple nor an easy task. It is difficult to free oneself from the mental-

10 S. Bastianel, L. Di Pinto, Biblijne podstawy etyki [Per una fondazione biblica dell'etica], Kraków 1994, pp. 15-16.

11 Ibidem, p. 17. 
ity of the enslaved. Egyptian slavery not only posed a threat of losing one's life but above all of losing one's national and religious identity; there was a risk that people would forget what free life and human dignity actually meant. Indeed, some Israelites forgot their freedom and became accustomed to the state of slavery; becoming used to enslavement, giving up the pursuit of freedom, and losing awareness of dignity proved to be among the greatest threats.

God wants the Chosen People to break out of slavery and become free. However, on their path to the Promised Land they are to face years of wandering through the desert. God chose this path even though it was not the shortest route to Canaan. Nevertheless, it was God's wish to be the guide of his people in this difficult journey.

In God's plans the desert was not intended to be the ultimate goal; rather, it was chosen as the only proper location whereby more important objectives could be achieved. The Israelites' journey through the desert would not only teach them to be humble and put their trust in God, but they would also become truly aware of their great dignity as the Chosen People (see Deuteronomy 7:7-8).

Although the desert experience caused many Israelites to grumble and rebel, the Bible reveals that this was a valuable period in the history of Israel and also a necessary one (e.g. Exodus 13, 17-18; Leviticus 23, 33-34). It was a sacred and crucial time for the Chosen People, and God's pedagogy, filled with wisdom, used it to prepare them for their life in Canaan. This time was essential as it allowed a generation being used to easy ways out and shortcuts they had learnt in Egypt to die and be replaced by a new generation hardened by different experiences $^{12}$. Those who entered the Promised Land were already born free. Although their freedom was difficult, it was the only way to prepare them for life in their own homeland.

God continues to stay with his people for the entire trial. Through this act, he proves to be the ultimate educator because if education is to succeed, a teacher needs to always be there for their pupils to gradually introduce them to the laws and their observance: 'Listen to ad-

12 D. Rops, Od Abrahama do Chrystusa, Warsaw 1955, p. 124. 
vice and accept instruction, that you may gain wisdom for the future' (Proverbs 19:20).

By guiding Israel and accompanying his people in the desert, God is reflective of a good parent raising a child: 'And in the wilderness, where you saw how the Lord your God carried you, just as one carries a child, all the way that you travelled until you reached this place' (Deuteronomy 1:31). The suffering experienced in the desert forms an integral part of the work of salvation and has a profound educational meaning.

One of the most important elements of God's pedagogy adopted with respect to the Chosen People is God's commandments, or the Decalogue, passed on by Moses ${ }^{13}$. The Decalogue rose to the central position in Israel's life, and the commandments became special norms that organised the relationship with God and other people. One of the first gifts offered to the liberated Hebrews, observant of the Law that was handed to them, was a condition for them to keep and make proper use of the gift of freedom. According to God's pedagogy these gifts are to be passed on to others; however, this can only happen once they have radically changed and redefined the identity of the original beneficiaries themselves.

Consequently, the Decalogue is more than a mere code of ethics and it lays the foundations for a system of education - not only in the Israeli community but also in the educational practice of people of all cultures. It is impossible to imagine education without a system of ethical values which, regardless of ideology, will always be based on the most original, primeval source - the Decalogue.

The Chosen People were not only to be a people educated by God but, by his will, also the ones that educate others. Accordingly, Deuteronomy 4:6 reads: 'You must observe them [the statutes and ordinances] diligently, for this will show your wisdom and discernment to the peoples, who, when they hear all these statutes, will say, "Surely this great nation is a wise and discerning people!"”.

13 G. von Rad, Teologia Starego Testamentu, Warsaw 1986, p. 153. 
The fundamental principle that allows us to understand the history of the Chosen People as a history of an educational relationship is also expressed in the Book of Deuteronomy: 'Know then in your heart that as a parent disciplines a child so the Lord your God disciplines you' (Deuteronomy 8:5).

The basic law that regulates people's mutual relations, and therefore their educational contacts, is the commandment to love your neighbour, and this is outlined in Leviticus 19:17-18: 'You shall not hate in your heart anyone of your kin; you shall reprove your neighbour, or you will incur guilt yourself. You shall not take vengeance or bear a grudge against any of your people, but you shall love your neighbour as yourself'.

No similar law existed in the contemporary world of Israel. Rather than sporadic acts of kindness towards others, this commandment relates to the entirety of human activity and people's internal attitude. As shown here, biblical texts dictate that one's duties towards others are on the same level as their duties towards God as both the former and the latter are strictly and inseparably connected. This is most visible in the text of the Decalogue. According to the Bible, religion and ethos cannot be separated; interpersonal ethos is a constitutive element of religion rather than just its result.

\section{Pedagogy of family life}

The Bible offers many passages dedicated to education in the family, which is presented as a result of human nature created and shaped by God. One passage says that God 'created humankind (...) male and female he created them' (Genesis 1:27), that he created them in his image, and that he proceeded to give them the mission to multiply and spread humankind (cf. Genesis 1:28). We later read that the first people received from God the gift of love, which encouraged them to strive to 'become one flesh' (Genesis 2:24). Consequently, the first people were summoned to create a union. The natural fruit of that union is a child ${ }^{14}$.

14 M. Filipiak, Biblijne podstawy teologii małżeństwa i rodziny $w$ Starym Testamencie, Lublin 1984, p. 45. 
The Bible praises a good family, offering texts about ideals of family life (see Psalms 128:1-6; Proverbs 31:10. 27-28. 30). There are many instances in the Old Testament which highlight the importance of marital stability and cohesion as the foundation of a healthy family. Such a family's endurance is based not only on the observance of the Law but also on people's love towards each other. While the Bible emphasises that the primary purpose of marriage is to have and raise children, it also indicates that love between spouses often plays a decisive role in maintaining the stability of marriage, even when a woman cannot conceive. For example, Elkanah loves his wife Hannah despite the fact that 'the Lord had closed her womb' (1 Samuel 1:5).

The Old Testament strongly condemns deeds that might threaten marital cohesion and family stability, particularly adultery and prostitution (e.g. Genesis 38:24; Exodus 20:14; Deuteronomy 22:22) ${ }^{15}$. All these threats can also damage family's educational role. Raising offspring is not easy, and the Bible demonstrates that education in the family is very difficult for a number of reasons. Firstly, the human heart is reluctant to accept wisdom (cf. Proverbs 22:15); secondly, people tend to be susceptible to bad influences (e.g. Proverbs 5:7-14) and are unwilling to listen to the voices of educators ${ }^{16}$. The Bible does not hide examples of failures in raising children, even in families of the highest social status. Examples include the story of the sons of the priest Eli, known for their scandalous, wicked behaviour (cf. 1 Samuel 2:12-13), or the drama of David who sees acts of wickedness committed by his sons (cf. 2 Samuel 13:21; 1 Kings 1:6). While pointing to the educational ideal, the Old Testament does not forget to immerse it in the highly specific and very real conditions of family life.

In the Old Testament one can find many texts in which a child is presented as a gift of God because, from the beginning of humankind, procreation has been given a special blessing: 'Be fruitful and multiply, and fill the earth and subdue it' (Genesis 1:28). There is no fear of a child in the Old Testament; every newborn child is welcome with gratitude and joy as a manifestation of a special blessing from God, and a child is seen

15 Cf. ibidem, pp. 126-131.

16 Ibidem, p. 185. 
as a gift from God through which he will enter human life (cf. 2 Maccabees 7:22-23; Psalms 139:13-15).

Another important aspect of the pedagogy of the Old Testament may be found in the history of the patriarchs and in the prophetic books. However, such a broad and significant topic would require a separate study.

\section{Conclusion}

It is a truism to say that education is one of the most important issues in human development. Traces of educational activity and its records may be found in the oldest documents that show the beginnings of human culture and civilisation, and the Bible is undoubtedly one of the oldest and most important of them. While the Scripture is first and foremost the book of salvation, its message lies at the foundation of educational ideas, referring to education not only in its strictly religious sense but also in more general terms. It offers elements of anthropology, i.e. truth about humankind, which in the past provided-and continue to provide today - the basis for every educational system that is truly focused on the interests and wellbeing of a child. Knowing the basics and elements of pedagogy presented in the Old Testament is necessary to understand how it was first implemented in the family life of Israel and then in the teachings of schools operating at synagogues. A more detailed presentation of these issues lies outside the purview of this article.

\section{References}

Bagrowicz J., Jankowski S., 'Pan, Bóg twój, wychowuje ciebie' (Deuteronomy, 8:5), Toruń: Wydawnictwo Uniwersytetu Mikołaja Kopernika, 2005.

Bastianel S., Di Pinto L., Biblijne podstawy etyki etyki, Kraków: Wyd. WAM, 1994.

Civil M., Education (Mesopotamia). In: The Anchor Bible Dictionary, Friedman

D.N., New York 1992, Vol. 2 D-G, pp. 301-305. 
Marrou H. I., Historia wychowania w starożytności, Warsaw: Państwowy Instytut Wydawniczy, 1969.

Gioia F., Metodi e ideali educativi dell' Antico Israele e del Vicino Oriente, Vatican City: Libreria Editrice Vaticana, 2008.

Chrostowski W., Wychowanie i ksztatcenie młodego pokolenia $w$ przedwygnaniowym Izraelu. In: idem, Asyryjska diaspora Izraelitów i inne studia, Warsaw: Vocatio, 2003.

Crenshaw J. L., Education in Ancien Israel: Accross the Deadening Silence, New York: Yale University Press, 1998.

Filipiak M., Biblia o człowieku, Lublin: Towarszystwo Naukowe KUL, 1979.

Filipiak M., Biblijne podstawy teologii małżeństwa i rodziny w Starym Testamencie, Lublin: Diecezjalny Ośrodek Duszpasterstwa Rodzin, 1984.

JGi-PG, Przymierze. In: Słownik Teologii Biblijnej, ed. X. Leon-Dufour, 825-833. Poznań: Pallotinum, 1973.

Kułaczkowski J., Biblijne zasady wychowania rodzinnego w świetle Mądrości Syracha, Rzeszów 1998.

Muszyński H., "Bóg Abrahama, Izaaka i Jakuba, Bóg Ojców naszych", Ateneum Kapłańskie 114 (1990): 6-9.

Rad von G., Teologia Starego Testamentu, Warsaw: PAX, 1986.

Rops-Daniel H.., Od Abrahama do Chrystusa, Warsaw: PAX, 1955

Townsend J. T., Education (Greco-Roman). In: The Anchor Bible Dictionary, Friedman D. N., Friedman D. N., New York 1992, Vol. 2 D-G, p. 312-317. 